\title{
Quality Growth Focusing on Environmental Sustainability
}

Transformation and sustainability is one of the central themes of the quality growth agenda. Generally, emphasis is put on the necessity of transforming the actual economic structure into a more sustainable one. The outcome document of the United Nations Summit for the adoption of the post-2015 development agenda, "Transforming Our World: the 2030 Agenda for Sustainable Development," states in its preamble: "We are determined to protect the planet from degradation, including through sustainable consumption and production, sustainably managing its natural resources and taking urgent action on climate change, so that it can support the needs of the present and future generations" (italics added) (United Nations 2015). Concrete goals and targets have been established for, among other things, the three priority areas: sustainable consumption and production (Goal 12 of Sustainable Development Goals (SDGs) adopted at the UN summit), sustainable management of natural resources (Goals 14 and 15), and urgent action on climate change (Goal 13). This chapter discusses effective approaches toward quality growth, focusing particularly on environmental sustainability related to Goals $12,13,14$, and 15 of the SDGs. Section 7.1 of this chapter focuses mainly on the idea of a circular economy, Sect. 7.2 discusses the green economy, and Sect. 7.3 examines natural capital, transformation and sustainable growth, with some concluding remarks at the end.

\subsection{Sustainable Consumption and Production: Mainstreaming of the Circular Economy}

As a target of Goal 12 (Target 12.1), the UN 2030 Agenda states the importance of implementation of the 10-Year Framework of Programs on Sustainable Consumption and Production Patterns (10YFP). It was adopted at the United Nations Conference on Sustainable Development (Rio + 20 Conference) in its Outcome Document The Future We Want (United Nations Conference on Sustainable Development 2012). The 10YFP will develop, replicate and scale up Sustainable Consumption and Production (SCP) and resource efficiency initiatives at national and regional levels, decoupling environmental degradation and resource use from economic growth, and thus increase the net contribution of economic activities to poverty eradication and social development. An effective approach to SCP is to "substantially reduce waste generation through prevention, reduction, recycling and reuse" (Target 12.5). From this viewpoint, the concept of a circular economy deserves special attention, as it entails markets that give incentives to reusing products, rather than scraping them, and then extracting new resources ${ }^{1}$ : In such an economy, all forms of waste, including clothes, scrap metal and obsolete electronics, are returned to the economy or used more efficiently. This can provide a way to not only protect the environment 
but also use natural resources more wisely, develop new sectors, create new jobs and develop new capabilities (UNCTAD 2017, 1). As such, transformation of industrial structures to strengthen the circular economy could be an effective path to attain quality growth in terms of environmental sustainability and inclusive development. This will result in fundamental changes in the way that our societies produce and consume goods and services.

One of the industrial sectors that has high potential for strengthening the circular economy is the automobile industry. In many countries, there are many places where old vehicles are abandoned as garbage around cities. Diverse resources could be recovered and recycled from these vehicles, reducing the risk of environmental deterioration and creating jobs, and thus decoupling growth from environmental degradation. Case 7.1 below elaborates on the process of a circular economy of automobiles. Another sector with high potential for the circular economy is the electronics industry. As the World Bank (2020) states, "Global Value Chains (GVCs) have the potential to turn [electronic]waste (e-waste) into valuable resources ... Ewaste flows should be viewed as sources of inputs for next-generation products. The World Economic Forum's call for a circular electronics value chain represents a model of sustainability that is difficult to envisage without GVCs" (123, italics are added). The report points out that Japan has e-waste management laws that make manufacturers and retailers responsible for taking back used home appliances, recycling them, and publishing the cost of recycling.

\subsubsection{Case 7.1: Enhancing the Circular Economy of the Automobile Industry}

Today, efficient car recycling has become a major challenge in developing countries. Used automobiles must be dismantled properly, or otherwise, this can be a major cause of environmental pollution. One Japanese company, Kaiho Industry, has been a pioneer in reusing and recycling used cars in many countries-including Japan and some developing countries. If the production of cars through global value chains can be perceived as an arterial industry, the recirculation of used cars could be considered to be a venous industry. In order to achieve Goal 8.3, enhancement of venous industries are essential. This company addresses the challenge with its experience and technology. It developed the "KRA system," an automobile recycling total management networking system, to manage every process from vehicle purchase to overseas sales while maintaining traceability of vehicle quality. The worldwide network covers about 90 countries. The "KRA system" enables all automobile recycling companies to participate in the fair trade of used cars. It is a system that is indispensable for overseas expansion of venous industries. Currently, the company is running projects in countries such as Brazil, India, Indonesia, and Kenya, where it has established recycling centers with public or private partnerships. The company established a pilot plant and an international recycling education center (IREC) in Brazil to disseminate "correct car recycling methods" and to conduct an automobile recycling business.

In 2010, the company created its own standard, named "JRS (Japan Reuse Standard)," to evaluate the quality of used engines of automobiles. In 2013, based on the JRS, the used engine evaluation standard, referred to as "PAS 777," was officially issued by the British Standards Institute as a publicly available specification. Since the quality of used engines evaluated by this standard is clear, customers around the world can purchase them without worry. Indeed, these activities are a critical part of automobile value chains in terms of the improvement of resource efficiency in consumption and production and decoupling economic growth from environmental degradation, as indicated in Goal 8 of the SDGs (Target 8.3). UNDP has approved Kaiho Industry's accession to the Business Call to Action (BCtA) as the first SME (small or 
medium-sized enterprise) in a venous industry in Japan. $^{2}$

Improvements in the efficient use of energy and materials in the process of production are a cross-cutting approach to strengthening sustainable production of goods and services. In this regard, a management system known as Kaizen, along with related approaches including Total Quality Management (TQM), could be an effective vehicle for this approach. This approach seeks to achieve higher quality and productivity through continuous improvement, while eliminating among other things, Muda (waste). Case 7.2 considers the Kaizen approach from a sustainable production perspective.

\subsubsection{Case 7.2: Kaizen, TQM and Sustainable Growth}

A core method of Kaizen is to eliminate Muri (overloading), Muda (waste), and Mura (inconsistency) from the worksite through efficient utilization of labor, energy, materials, and equipment. As such, the concept of environmental sustainability has been intrinsically incorporated into Kaizen, TQM and related approaches in Japan from the inception phase of the introduction of these approaches (see Chap. 4 ). It should also be highlighted that the widespread dissemination of Kaizen, QCC (Quality Control Circle), TQC (Total Quality Control), TQM, and related approaches have contributed significantly to the sustainable growth of Japan since the 1970s. As the Development Bank of Japan and Japan Economic Research Institute (2003) emphasize, "One of the significant impacts of Japanese TQC/TQM is often explained through descriptions of the development of the car industry after the oil crises in the 1970s. During this period, TQC was extended to activities for energy conservation and measures for resource maintenance. It greatly impacted on various industries and became more securely established as a valuable quality framework for Japanese industrial development" (46) (see Chap. 4).

\subsection{Strengthening the Green Economy: Sustainable Use of Terrestrial Ecosystem, Sustainable Management of Forests, and Reversal of Land Degradation}

The UN outcome document on the SDGs establishes that Goal 15 aims to protect, restore and promote sustainable use of terrestrial ecosystems, sustainably manage forests, combat desertification, halt and reverse land degradation, and cease biodiversity loss. For Goal 15, the concept of a green economy deserves special attention. The Rio +20 Conference in 2012 focused on the development of a green economy. Its outcome document stated that, "we express our determination to address the themes of the conference, namely a green economy in the context of sustainable development and poverty reduction, and the institutional framework for sustainable development" (United Nations Conference on Sustainable Development 2012, 2). A 'green economy' is a pathway to sustainable development and poverty reduction, as highlighted by the United Nations Environment Program's (UNEP) report prepared for the Rio +20 Conference (UNEP 2011). UNEP defines a green economy as one that results in "improved human well-being and social equity, while significantly reducing environmental risks and ecological scarcities" (UNEP 2011, 9). A concept similar to the green economy is 'green growth'. OECD provides the following definition of green growth: "Green growth means fostering economic growth and development, while ensuring that natural assets continue to provide the resources and environmental services on which our well-being relies" (OECD 2011, 4).

As such, from the quality growth perspective, there is a close relationship between the transition to a green economy and the eradication of poverty, as well as inclusive development. Productive sectors like agriculture, forestry, fishery and water management are sectors with high potential for poverty reduction as well as possible areas for a green economy. Nevertheless, the 
transition to a green economy will not automatically address all poverty issues. On the other hand, the transition to a green economy will not be realized without people's support and cooperation; hence, it needs to contain a povertyreduction orientation if it is to succeed. Thus, as UNEP correctly points out, "a pro-poor orientation must be superimposed on any green economy initiative" and, furthermore, "a green economy must not only be consistent with [the] objective [of Millennium Development Goals (MDGs)], but must also ensure that policies and investments geared towards reducing environmental risks and scarcities are compatible and ameliorating global poverty and social inequality" (UNEP 2011, 20). Therefore, this chapter often utilizes the term 'inclusive green economy' in order to make explicit the inherent needs for a green economy to have a pro-poor and inclusive orientation.

From this viewpoint, this chapter examines three cases that can be broadly categorized as 'sustainable and inclusive development' and are related to the areas of agriculture, forestry and water management. The case studies provide insights into how to achieve the dual objectives of reducing environmental risks and poverty and inequality, and realizing, according to the definition given above, an inclusive green economy. In particular, we will discuss how innovative solutions were created during the process toward the attainment of both these goals. All selected cases are related to forests in tropical regions, while they have different climatic and topographic conditions. Two cases-the Amazon rainforest and Panama Canal watershed - are in a humid tropical zone, while the third case, in Kenya, is mainly located in an arid or semi-arid zone. Topographically, the Panama Canal watershed is in mountainous areas while the Amazon rainforest is located on low, flat land. In contrast to the other two cases, Kenya contains both low and high lands. Hence, all these regions face different risks of environmental deterioration. However, they face common challenges in simultaneously achieving the conservation of the environment and improvement of livelihoods of those who live in these regions.
A remarkable experience of consolidating a green economy in the Amazon Rainforest is examined in Case 7.3 below.

\subsubsection{Case 7.3: Strengthening the Green Economy with Innovative Practices: Agroforestry in the Amazon Rainforest}

As natural capital, tropical rainforests are extremely important for a green economy. They are rich in biodiversity and function as huge reservoirs of carbon dioxide, but they are increasingly becoming endangered. Indeed, significant losses have already occurred worldwide. Shifting agriculture was thought to account for about onethird of the deforestation in Amazonia, while cattle ranching was responsible for at least half of the forest retreat (Smith et al. 1998). It was common practice for illegally deforested land to be used for a number of years as pasture for cattle ranching and other purposes and for the land then to be abandoned when its fertility was almost lost. Therefore, the challenge in the Amazon rainforest lies not only in the establishment of sustainable and inclusive agroforestry for small farmers but also for the regeneration of abandoned land.

In this context, in the state of Pará in the Brazilian Amazon region, crop diversification and critical production experience in Tomé-Açu, led to the development of an innovative agroforestry model (hereafter referred to as the ToméAçu model) that is well suited to the Amazonian environment according to, among others, a study by Piekielek (2010). This study highlights the model's main characteristics: "The basis of this model is that production is most successful when it mimics some of the important natural processes of the tropical forest. Crops are interplanted, grown with associated crops that complement each other by providing shade and that allow farmers to focus intensively on smaller plots of land. Crops are planted to establish a series of successive harvests ... Crops are intensely fertilized with a variety of organic compounds, 
including organic wastes, natural fertilizer compounds, charcoal, and bokashi, a type of fermented compost developed in Japan, to ensure that associated crops do not compete for nutrients" (Piekielek 2010, 20).

As such, in the Tomé-Açu model, key factors include a combination of crops and trees and the sequence for planting them. For example, cacao plants need $40 \%$ shade, so bananas are the ideal neighbor, because they grow faster than cacao and provide protection from direct sun, heavy rain and strong winds. Between the rows of banana and cacao, at 24-m intervals, tabereba (Spondias mombin) fruit trees, açai palm trees, and/or mahogany can be planted. Among these tree species, corn and rice can also be planted. When planting diversified species, it is necessary to take particular care that the spacing between the different species should be appropriate. Perennial and arboreal species tend to compete against each other for space in which to grow. Some consume a lot of water while others need more fertilizer. Michinori Konagano, one of the leaders of Tomé-Açu Multipurpose Agricultural Cooperative (CAMTA), who made a substantial contribution to the development of the ToméAçu model, has devised a long-term cultivation plan, featuring crop species that are all economically reliable. $^{3}$

For example, the following is a model case for the overall long-term development process of an 'agroforest'. The tropical climate encourages the rapid growth of plants. Rice is harvested in the first year, so farmers are sure of some income. In the second year, the banana and black pepper produce their fruits. From the third year, as the plants continue to grow, the farmland turns increasingly bushy. Banana plants bear fruit for several years. Cacao grows in the shade of the banana leaves. Black pepper plants increase production each year throughout their life spans of about eight years. Tabereba, açai palm and mahogany grow quickly in their early years. Cacao starts to bear fruit from the third year. By the sixth year, cacao will have grown to a height of three meters, açai palms to five meters and tabereba and mahogany to more than eight meters. The farm becomes dense like a forest. Açai palm and tabereba are now ready for harvest. Cacao production begins to overtake that of pepper, giving farmers another source of revenue. Banana and black pepper plants die off after seven years. Cacao carries on producing in the shade of tall tabereba and mahogany trees. At this point, the farm turns into a forest garden. In this way, the agroforestry in Tomé-Açu allows a succession of productive plants, providing farmers with a steady annual income. Which species and when they are planted depends on the discretion of the farm and the farmer. Factors affecting the decision include location, soil condition, water availability, management efficiency and the optimum harvesting period. In this process, what matters is the farmers' learning and enhancing the capacity of learning to learn.

The model is inclusive and sustainable. Using this model, 25 ha of agroforestry produce the same level of income as 1000 ha of cattle ranching. Therefore, the income from 25 ha of agroforestry is forty times that of the cattle ranching from the same amount of land. Moreover, the agroforestry creates jobs for ten to twenty workers in 25 ha, whereas the ranching needs $50-75$ ha to create a single job (Yamada 2003). In their study Smith et al. (1998, 5) emphasize the commercial feasibility of the Tomé-Açu model: "Agroforestry is an ancient practice in Amazonia. Many indigenous peoples plant a mixture of tree and annual crops in their fields, and traditional, small-scale farmers usually maintain a rich assortment of tree, bush, and herbaceous plants in their home gardens." However, the authors emphasize that commercial agroforestry in plots away from home gardens is the main focus of their study, because it can play an especially important role in slowing deforestation and improving rural livelihoods (Smith et al. 1998, 7). As the study finds, "Tomé-Açu in Para, settled by Japanese immigrants in the late 1920s and early 1930s, became an innovative pole for agroforestry systems geared to markets starting in the 1970s" (Smith et al. 1998, 8). 
In one of its recent research projects, the Brazilian Agricultural Research Corporation (Embrapa) Eastern Amazon Center found striking similarities between the characteristics of agroforest soils of this model and those of the natural forest soil of the Amazon rainforest. This may imply the resilience of the agroforest ecosystem in terms of not only flora but also fauna. In fact, as agroforests have grown over the years, the number of observed bird species has increased, showing how agroforestry supports both ecosystem recovery in the Amazon and farmers' livelihoods. In acknowledgment of the establishment of the successful model, on December 1, 2010, the Tomé-Açu Multipurpose Agricultural Cooperative (CAMTA) was awarded the first Brazil Regional Development Contribution Prize by the Federal Government of Brazil (Hosono 2013).

Several Japanese companies, including Meiji and FRUTAFRUTA, commercialize products of Tomé-Açu for the Japanese market. Agroforestry Chocolate produced by Meiji received the EcoProducts Award as well as the Award of the Environment Minister of Japan. Recently CAMTA and Meiji started to work together through an agreement for cooperation in the development of technology of fermentation and for the sustainable trade of cacao. As the web page of FRUTAFRUTA explains, "Charmed by the passion and diligence of Japanese immigrants engaged in agroforestry through trial and error with numerous crops amid difficult conditions, FRUTAFRUTA directly imports the fruit ingredients and other types of ingredients produced through agroforestry from CAMTA in order to support the development of their agroforestry."

The case of the Panama Canal watershed conservation area is also relevant for the aforementioned challenges in attaining both conservation of the environment and inclusive development. In Panama, there had been concerns about water, a key natural capital, for the Panama Canal. The problem of how to conserve the watershed in the area while at the same time reducing poverty became a critical issue for the country. Case 7.4 explores a process of consolidating the inclusive green economy in Panama.

\subsubsection{Case 7.4: From Slash-and-Burn Farming to Sustainable Agriculture: Panama Canal Watershed Conservation}

Land reclamation in the Panama Canal watershed has been progressing because of recent increases in population in the area. Consequently, there are fears that forest degradation and a decline in the replenishment of water-source functions in the watershed will have an impact on the operation of the Panama Canal. Since the 1950s, the Panama Canal watershed has been experiencing deforestation resulting from a number of factors, including expanding farmland and pasture, burning and subsequent extensive pasturage, clearing associated with slash-and-burn farming, and overexploitation. Forest degradation, as exemplified by deforestation, soil degradation, soil erosion, and the loss of biodiversity, is a major environmental concern to the development agenda for Panama. There are concerns that a fall in the capacity for water-source conservation/ recharging as a result of forest degradation is affecting navigation along the Panama Canal.

Concerns about environmental conservation and navigation of the Panama Canal during the dry season increased markedly after the El Niño climate event in 1997. These circumstances prompted the Panamanian government in 1997 to establish a law concerning land use planning in the Panama Canal watershed. Among other targets, this law called for reducing the proportion of pasture and increasing that of afforested land for the purpose of forest conservation and appropriate land use. Attempts to achieve these targets led the National Environment Authority (ANAM), which was reorganized from the National Natural Resources Institute (INRENARE) in 1998, to formulate administrative guidelines on the relevant policy issues. The guidelines included a plan to promote participatory forest management, whereby farmers in the watershed would understand the importance of forest conservation and practice appropriate land use. In this context, Panama-Japan technical cooperation on the Panama Canal Watershed 
Conservation Project (PROCCAPA) began in 2000.

According to a report on this project, the conversion from slash-and-burn farming to sustainable farming could be facilitated through the following three approaches (JICA 2004, 33): (1) converting to a more effective alternative farming method to produce staple foods; (2) increasing cash earnings to a level sufficient to purchase staple foods; and (3) abandoning agriculture completely. Of these alternatives, the project considered the first one to be the most realistic one. In this regard, paddy rice production (wet-rice culture) was one of the most effective alternatives for farmers to turn from their slash-and-burn farming to more sustainable agriculture to grow staple crops. At the same time, it was crucial to improve and maintain soil fertility in order to generate considerable increases in the productivity of the land through the introduction of compost and a number of other improvement methods. Forestation and reforestation were also promoted. This involved the planting of three types of trees: trees for timber, fruit trees and trees for medicinal use. The planting of trees for timber had a number of environmental benefits: the improvement of soil, conservation of the watershed through small dams constructed by farmers, production of charcoal, and the avoidance of landslides (JICA 2005, 26). Organic agriculture was also encouraged, including the experimental introduction of several different materials: bokashi fertilizer, mimizu compost, natural insecticides and so forth. Environmentally friendly cultivation methods were also introduced, including contour line cultivation, alley cropping (different crops planted in parallel alleys), the combination of coffee with laurel trees, and so on. Charcoal kilns and ponds for tilapia culture were also introduced.

The adaptation of these technologies was carried out jointly by farmers and other stakeholders in the Panama-Japan project. However, the leading role was played by farmers. In this process, the empowerment and enhancement of consciousness of individual farmers and their organizations were remarkable, a point highlighted in the project's evaluation report (JICA 2005, 60): "the most significant impact is that the Farmers' Association of the Upper Panama Canal Watershed (APRODECA) was created spontaneously by farmers." In the words of the report: "Group organization strategy works as the mechanism for expansion of the techniques that is a part of farmers' empowerment. For example, the magnitude of training was multiplied considerably by the group activities." The report emphasized that group organization strategies contributed to the "creation of social capital." There was an increase in farmers' consciousness of their situation. The report notes that: "they became aware of the importance of reforestation and are implementing small-scale tree planting in water source areas and for the production of firewood, charcoal and wood vinegar to improve the quality of their life. In addition, farmers become aware that practicing the new techniques instead of slash and burn contributes to the protection of their environment and watershed conservation" (JICA 2005, 63). There were increases in the level of women's participation and their empowerment was attained throughout this project. This process is explained eloquently in an interview given in 2003 by a woman who participated in the project: "When slash and burn was practiced, farms were so far and steep that it was difficult for us, women, to participate in farming. Therefore, we depended on men for food production. In contrast, in paddy rice and other crop farming, which are promoted by the project, farms are located near our houses and the work is not so hard, so we women can participate. We would like to engage more in production work and improve our livelihood" (JICA 2005, 30).

In the bulletin of the Panama Canal Authority (ACP), the administrator of ACP and other government officials all agreed that the experience gained from the project could be put to good use in other parts of the Canal watershed. The ACP administrator was quoted as saying that he was considering applying this model to other regions. The Panamanian government is considering granting land certificates to small farmers involved in the project through the Inter- 
institutional Commission of the Canal Watershed (CICH). On a broader scale, National Geographic, has written about the project (JICA 2005, 60). As one of the post-PROCCAPA projects, the Project for the Participatory Community Development and Integrated Management of the Alhajuela Lake Subwatershed (Alhajuela Project) was implemented by ANAM and JICA between 2006 and 2011. Based on experiences of this project-as well as PROCCAPA_Panama and Japan implemented the International Course on Participatory Integrated Watershed Management during 2014-2017, and started the International Course on Ecosystem Based Participatory Watershed Management from 2018 for 16 countries in Latin America.

As stated in Chap. 5, one of the most serious challenges faced by Kenya is to cope with desertification of arid and semi-arid land (ASAL) that is vulnerable to global warming and climate change and is characterized by a very high incidence of poverty. Several innovative solutions to address these issues have been developed and brought into the mainstream. One of the most important of these is 'social forestry', which is defined as a "form of forestry which aims at both the improvement of the economy and the preservation of forest resources, by entrusting local people with the management and ownership of the forest resources" (JICA 2003). It is a very similar concept to the inclusive green economy as a pathway to sustainable development and poverty reduction. An effective instrument developed and disseminated to promote social forestry has been the 'farm forest', as is explained below.

\subsubsection{Case 7.5: Fight Against Desertification: Social Forestry in Semi-Arid Kenya}

A period of more than twenty years has seen the introduction of three consecutive projects to strengthen social forestry in semi-arid areas of Kenya - with remarkable results. The first of these, the Social Forestry Training Project
(SFTP), was carried out from 1987 to 1997 , and aimed to develop practical techniques for planting and tending trees for the establishment of a farm forest. In particular, the project focused on developing tree nursery and tree planting technologies in semi-arid areas as well as to provide social forestry training for farmers and government staff. The second project, the Social Forestry Extension Model Development Project (SOFEM, 1997-2002), saw the introduction of forestation nurturing technologies applicable to farmers and suitable for the local environment. "The Project developed systems such as a costsharing system, a seed/seedling plan information system, a farmer to farmer extension method, and a core farmer selecting method. Their effectiveness was proved through actual farm forestry preparation practice" (JICA 2003, 3). Therefore, the project effectively developed a social forestry extension model, which is based on the establishment of farm forests by local residents (JICA 2009, 9).

The third project, the Intensified Social Forestry Project (ISFP 2004-9), consolidated the main lessons learned and key technologies acquired in the previous two projects. Although the previous two projects achieved their goals, neither of them was able to reach a substantial number of farmers (FAO et al. 2011, 12). Therefore, ISFP established, among others, a "Farmer Field School" (FFS) as a means to extend social forestry. A total of 94 FFSs conducted by the Kenyan Forest Service (KFS) cultivated the abilities of a considerable number of farmer facilitators. Farmer-run FFSs utilizing farmer facilitators had the same effect as a FFS by KFS. The Evaluation Study Team on ISFP confirmed "high evaluation and acknowledgements of FFSs by those who not only introduced FFSs in the initial time of the Project but also by those who implemented, managed and operated FFSs including target groups" (JICA 2009, 14-15).

As such, building on the country's past experiences, ISFP brought a new dimension to forestry extension, creating a systematic extension management system. The FFS methodology mentioned above was introduced with assistance 
from the United Nations' Food and Agriculture Organization (FAO). Previously, the FFS methodology had been principally applied to agricultural extension service delivery in the country. The ISFP customized the FFSs to farm forestry, leading to the implementation of the Farm Forestry Field School (FFFS) approach. Currently this approach is the standard method for farm forestry extension in KFS and is widely used in other districts and projects in Kenya. With help from the FAO, KFS has further developed the Livelihood Farmer Field School, which was based on the FFFS (FAO et al. 2011, 13).

In short, throughout social forestry projects in Kenya, with the Kenya Forestry Research Institute (KEFRI) as an implementing agency, basic tree nursery and tree planting technology in arid and semi-arid regions was developed and core farmers were supported to provide a base for the extension of the model developed under the Kenya-Japan technical cooperation projects. For the extension of this model, the FFS approach, an existing proven extension approach in the agricultural sector, was applied to the forestry sector through innovative adjustments to the methodology. Through the FFS, techniques such as seedling production, fruit tree planting (mango, grevillea, and others), poultry raising, vegetable cultivation, utilization of compost, and creation of woodlots were disseminated (JICA 2013). As a result of all these measures, KFS, Kenya Forestry Research Institute, farmer facilitators and farmers, as well as JICA, have developed appropriate solutions incrementally to address the challenges mentioned above. They are based on a series of technological and institutional innovations and they have produced synergies to take full advantage of social forestry.

From their inception, the three projects entrusted local people with the management and ownership of forest resources. This approach is the essence of social forestry. The FFS has developed ownership, strengthened communities, and increased farmers' capacities in terms of knowledge about forestry practices (JICA 2009, 15). Through FFS, individual farmers, farmers' groups, and the surrounding farmers are continuing to raise and produce seedlings and plant trees. They have started to sell social forestry products such as mangoes, seedlings, lumber, and firewood. Through these activities, farmers are increasing their awareness of methods to improve their livelihoods. Wider extension activities related to social forestry are expected, as graduate farmers from FFS give advice about agriculture and social forestry to neighboring and surrounding area farmers, which indicates the creation of a network (JICA 2009, 15-16). The most important achievement is that the growth of trees contributes to the improvement of the livelihoods of farmers, attaining the overall goal of ensuring that social forestry projects contribute toward the development of a green economy. It appears that social capital has been strengthened and there is a greater sense of empowerment among the people. The final evaluation of IFSP emphasized dynamic group activities, including songs and dances celebrating FFS. While emphasizing the joy of solidified farmer groups working and studying together, the group plays a core role in assuming the continuation of activities and keeps farmers interested in FFS. The Green Zone project of the African Development Bank adopted the FFS approach in its forestry preservation activities in areas of high potential.

\subsection{Natural Capital, Transformation, and Sustainable Growth}

The afore-cited documents (Sect. 7.1) examine a general framework of the relationship between transformation and quality growth and, in particular, sustainable growth in terms of environment and eco-diversity. However, special attention to these aspects is needed in cases of transformation in which 'natural capital' is the essential endowment that enables the transformation. While natural capital assets are not created by human activity, their quality and capacity to yield goods and services, and therefore their value as productive inputs, are affected by it (OECD 2008, 30). Understanding the synergies 
between different attributes of quality growth is normally the most difficult in cases where natural capital plays the crucial part of transformation. Two of the notable cases that were discussed in Chap. 3, Cerrado agriculture and Chile's salmon aquaculture, are cases in which human activity, particularly technological innovation or adaptation increased the value of natural capital: Cerrado land and southern Chile's seashore. A remarkable transformation of a vast region of Cerrado and southern Chile took place by utilizing natural capital, which was not necessarily used before as an input for the production of goods and services. However, special attention has been needed to address the risk of sustainability due to the possible degradation of or other consequences to the natural capital.

Analysis of Cases 7.6 and 7.7 could provide clues toward developing an effective approach to quality growth with sustainability and inclusiveness, in cases in which 'natural capital' is the crucial endowment that enables the transformation. As discussed above, the quality of growth extends to green growth concepts. UN-ESCAP $(2013,27)$ argues that "Policies and investments that promote green growth seek to improve the "eco-efficiency" of growth, which involves minimizing resources use and negative environment impacts per unit of benefit generated by the economy ... Green growth is a pre-requisite for building a green economy characterized by substantially increased investments in economic activities that build on and enhance the earth's natural capital or reduce ecological scarcities and environmental risks ..." (italics added). Cases 7.6 and 7.7 are examples of efforts to promote this "broadly defined green growth," as cited above.

\subsubsection{Case 7.6: Natural Capital, Transformation, and Sustainable Growth: The Case of Cerrado Agriculture}

The Cerrado has become known as the savanna zone with the world's richest biodiversity. Plants in the Cerrado cope with the unique stresses of extreme nutrient shortages, high soil acidity, and high aluminum saturation, and are believed to have evolved to protect themselves against damage from ants and wildfires, making them a valuable genetic resource. ${ }^{4}$

In the case of the Cerrado agriculture, active environmental conservation measures were implemented from the outset. As well as adhering strictly to the $20 \%$ legal reserve $(50 \%$ in Tocantins and other states) in individual farms, to prevent the legal reserve areas from becoming a haphazard patchwork of points, efforts were advanced to create joint strengths of reserve land through a 'condominium' model, as well as the formation of micro-corridors of reserve land made up of individual reserves. Moreover, measures to preserve agricultural environments have been actively promoted, such as the introduction of contour cropping, crop rotation, and no-till farming (direct planting).

The government of Brazil conducted a series of broad and varied initiatives aimed at environmental conservation. In the Cerrado region, the government especially pursued a balance between Cerrado agricultural development policies and environmental conservation policies. This could be considered as a pioneering initiative for the sustainable transformation of unused land into fertile agricultural land. In 1998, Brazil enacted the Environmental Crimes Law, and in 2000 the Forest Code was amended to impose stricter legal reserve percentages on landowners and to enable the trading of reserve land with the land of other forested landowners. Also in 2000, the National System of Nature Conservation Units (SNUC) was established. This system was designed to organize categories for native reserves to both protect and restore the biodiversity found in their ecosystems.

The Environmental Conservation Expansion Program, which is meant to efficiently manage expansive areas of privately owned land using satellite imaging technology, was launched through Presidential Directive 7029 at the end of 2009, and the government also decided to introduce the Rural Environmental Registry (CAR, Cadastro Ambiental Rural, in 
Portuguese). ${ }^{5}$ In October 2012, the Ministry of Environment issued a decree that established the obligation to register all agricultural land in Brazil in accordance with CAR within a year (or in two years if authorized by the President). The National System of CAR (SiCAR; Sistema National de Cadastro Ambiental Rural, in Portuguese) was established by Presidential Directive in October 2012. Moreover, Brazil's environmental conservation policy was further strengthened by Law 12651 and Law 12727 (amendment to Law 12651), enforced in 2012.

The Ministry of the Environment purchased the RapidEye satellite pictures for the entire country to support the CAR. RapidEye acquires images of the Earth's surface from a constellation of five satellites in the same orbit (Sano 2019, 155). More than $90 \%$ of the country is covered by RapidEye images each year. Images from 2011, 2012, 2013, and 2014 are available on the geocatálogo Internet system. ${ }^{6}$ A set of approximately 14,500 images per year, each with less than $20 \%$ cloud cover is available on this system.

In spite of the impressive increase in agricultural production in Cerrado in the last 3-4 decades, land used by "Cerrado agriculture" has not increased as fast as the rate of production growth. This is due to the remarkable improvement of yield per hectare. According to the Brazilian Institute of Geography and Statistics (IBGE) farm census, $61.36 \%$ of the growth of agricultural production (soybeans, rice, edible beans, corn, cotton and coffee) in the Cerrado between 1970 and 2006 occurred as a result of yield growth, while the rest, $38.64 \%$, was due to expansion of the planted area (Hosono 2015).

According to an analysis of land use expansion based on two latest mappings of land use in the Brazilian Cerrado produced by interpreting Landsat satellite images in 2002 and 2013, land use in the entire Cerrado biome increased $3 \%$ points from $40 \%$ in 2002 to $43 \%$ in 2013 . "This leads to an average increase of $0.27 \%$ per year, which matches up with the work conducted by the Project of Deforestation Monitoring of the Brazilian Biomes by Satellite (PMDBBS) by IBAMA (2016)" (Sano 2019, 144). In this project, the average annual deforestation found in the years 2008/09-2010/2011 was $0.34 \%$, a rate much lower than the previous rates of deforestation. In 2013, approximately $43 \%$ of the Cerrado biome was used primarily for food and energy production. In other words, $55 \%$ of the Cerrado biome retained its natural vegetation. The remaining $2 \%$ consisted of water bodies, burned areas, and clouds/shadows present during the satellite overpasses. Of the $43 \%$ of the Cerrado biome used for food and energy production, cropland corresponded to $11.7 \%$ (8.5\% occupied by annual cropland and $3.2 \%$ by perennial cropland) and improved pasture to $29.5 \%$ (Sano 2019, 144).

Currently, due to the commitments on compliance with COP-15, the goals for the Brazilian Amazon and Cerrado are to reduce deforestation by 80 and $40 \%$ of the average deforestation found in 1996-2005 by 2020, respectively. ${ }^{7}$ For the agricultural sector, the National Plan for Low Carbon Emissions in Agriculture (ABC Plan initials in Portuguese) was established. Sano (2019) enlarges on the ABC Plan as follows:

[The] ABC plan includes the following actions: (1) Adoption of 5 million ha of the crop-livestockforest integration (ILPFS) system; (2) Reclamation of 15 million ha of degraded pastures through the fertilizer inputs and better management practices; (3) Reaching 8 million ha of no-till agriculture, a method of farming in which crop residues are left on the soil surface to reduce soil erosion by wind and rainfall and to increase the soil organic matter; (4) Encouraging the use of nitrogen biological fixation in 5.5 million ha; and (5) Expansion of reforestation by 3 million ha. As regards to no-till farming, this system has been widely adopted by farmers located in the Cerrado. In the same way, soybean producers are taking advantage of biological nitrogen fixation into the soils by a bacterium named Rhizobium. It is now helping the country to save billions of dollars in nitrogen chemical fertilizers. The goal of 3 million ha of reforestation was already reached in 2013. As for the integrated crop-livestock-forest (ILPFS) system, a type of mixed system or producing grains, meat, and timber simultaneously, it is advantageous for cattle ranchers facing pasture degradation, since it is one of the best choices for recovering the capacity of biomass productivity of degraded pastures. ILPFS is agronomically efficient, economically viable, socially fair (creating good jobs), and environmentally correct, and it presents similar characteristics to the no-till 
farming in the Cerrado. As such, it is expected that most cattle ranchers will adopt ILPFS within 1030 years. On the other hand, the use of Precision Agriculture (PA), which enables farmers to apply correct amounts of fertilizers, pesticides, and irrigation water, reducing environmental contamination of soils, surface water and groundwater, is still incipient in the Cerrado. However, geo-referenced soil sampling, and further production of prescription maps are the most relevant activities to PA in the Cerrado.

The UN document on the SDGs establishes in Goal 14 the importance of conservation and sustainable use of the oceans, seas and marine resources for sustainable development. More specifically, the SDGs aim to sustainably manage and protect marine and coastal ecosystems to avoid significant adverse impacts, including by strengthening their resilience and take action for their restoration, to achieve healthy and productive oceans (Target 14.2). In this context, in order to avoid overfishing and to conserve marine ecosystems, aquaculture of fish (i.e. fish farming) and shellfish has crucial implications for food security. Today, farmed fish correspond to half to the total harvest of fish in the world. As Chile has been a pioneer in salmon aquaculture, its experience of addressing challenges of sustainable development appears to be full of insights - in particular, in terms of managing marine resources by identifying sustainable levels of their use (carrying capacity) while supporting dynamic growth of the productive sector (Iizuka et al. 2016, 3). Case 7.7 elaborates on this experience in Chile.

\subsubsection{Case 7.7: Natural Capital, Transformation, and Sustainable Growth: The Case of Chile's Salmon Industry}

In the case of Chilean salmon farming, it was crucial to establish a regulatory framework for many aspects of the salmon industry, especially environmental and quality standards for the aquaculture industry. In other words, what was needed was so-called 'institutional infrastructure', including laws, regulations, and environment and quality standards. Mitsuo Sakai, who participated in the Japan Chile Technical Cooperation (PTTC) for salmon farming in 1980s noted that, "by starting technology transfer activities concerning feed development and fish disease control early, the PTTC project forestalled the problems the farming industry faced later, including concerns about the spread of salmonid bacterial kidney disease (BKD), and the paucity of feed for the feeding culture business that had traditionally used living feed rather than fish meal." He concluded by saying, "These technology transfer activities anticipated technical problems that would arise in the early stages of the development of the Chilean salmon industry, and thus devised precautionary measures, including the development of necessary technologies" (Sakai and Ishida 2002, 1554).

Two decades later, when the Chilean salmon industry achieved full-fledged development, it experienced a sanitary crisis caused by infectious salmon anemia (ISA) in 2007. This experience demonstrated how natural resource-based activities such as salmon sea farming need to be supported not only by advanced production technology but also by scientific knowledge of the local environment so that appropriate local regulatory institutions to manage the use of common resources can be established. This case also demonstrates that progress in production capabilities may not be sufficient to ensure longterm sustainability in natural resource-based industries in which natural capital plays an important role.

As a reaction to the sanitary crisis in 2007, institutional change took place in Chile: the Aquaculture Law to modify the existing General Law of Fishery and Aquaculture (LGPA) enacted in 2010 was an important milestone. This modification granted more authority to the government to ensure sustainable management of aquaculture. Concretely, it strengthened the role of the Undersecretariat of Fisheries and the National Fisheries Service (SERNAP) by regulating firms' activities concerning sanitary 
management of aquaculture and by creating a mechanism of concession rights and new institutions-barrios and macrozones - to manage sanitary conditions in production centers. In order to reduce the systemic risk of new diseases in the future, the National Fisheries Service also required salmon farming firms to group their cultivation centers into barrios, or production zones, according to geographical location. They also obliged firms operating in cultivation centers within the same barrio to synchronize their production calendars, providing for a three-month resting period to facilitate sanitary controls aimed at minimizing navigation time, often instrumental in transmitting pathogens (Iizuka and Zanlungo 2016).

The modification of LGPA was partly the outcome of a gradual and profound coevolutional change among stakeholders over the years (lizuka 2016, 169). One of the insights that can be drawn from the case of the salmon industry in Chile is "a general lesson in creating a non-traditional export industry based on natural resources in developing countries. This process often suffers from a lack of traditional institutions and local knowledge due to lack of prior history. If the industry successfully takes off and increases its scale, local environmental sustainability may collapse without a sound management system. The provision of institutions at an earlier stage to monitor sustainable environmental conditions would be critical for the sustainability of such economic activity" (Iizuka 2016, 171). As Lebdioni (2019), summarizes: "The Chilean case thus demonstrates how natural resource-based activities need to be supported not only by advanced production technology, but also by scientific knowledge of the local environment in order to establish appropriate local regulatory institutions to manage the use of common resources (Iizuka and Zanlungo 2016; Katz 2006). Such a local regulatory role can be seen as an input that has public goods characteristics and thus will be under-provided by the market" (14).

In recent years, large-scale red tides in Chilean coastal waters have caused serious damage to fisheries, including aquaculture. In this context, the recent Chile-Japan Cooperation Project for Development of Harmful Algal Bloom Monitoring Methods and Forecast System for Sustainable Aquaculture and Coastal Fisheries in Chile appears to be a highly relevant initiative. This project is being carried out under the framework of Science and Technology Research Partnership for Sustainable Development (SATREPS), with the participation of Chilean and Japanese universities, the Fisheries Development Institute of Chile (IFOP), and Japan Fisheries Research and Education Agency (FRA). It aims to identify microorganisms that propagate prior to red tide formation and termination, which are expected to serve as bloom dynamic indicators. The cooperative project aims to elucidate the mechanisms of red tide occurrence and termination, and to develop a red tide dynamics forecast system. The system will provide forecasts to fishery operators, and the information will be utilized to mitigate damage by red tides. The project will also devise red tide countermeasure proposals based on scientific evidence through industry, government, and academic collaboration. ${ }^{8}$

Furthermore, for SDG Goal 15, the UN 2030 Agenda establishes as one of its targets "to promote the implementation of sustainable management of all types of forests, halt deforestation, restore degraded forests and substantially increase afforestation and reforestation globally" (15.2). In this regard, monitoring data on deforestation and forest changes in the tropical regions is an effective approach to Goal 15. Case 7.8 discusses the JICA-JAXA Forest Early Warning System in the Tropics (JJ-FAST).

\subsubsection{Case 7.8: JICA-JAXA Forest Early Warning System in the Tropics (JJ-FAST) ${ }^{9}$}

Brazil has maintained a coherent surveillance system to protect its tropical forests for decades. Since 1988, the Brazilian National Institute for Space Research (INPE) has published statistics showing the area of forestland destroyed each year based on satellite images, and has continued to issue warnings regarding excessive 
deforestation. In 2004, the Plan of Action for the Prevention and Control of Deforestation in the Amazon (PPCDAM) and the Near Real-Time Deforestation Detection System (DETER) were initiated, making it possible to monitor logging activity on a fortnightly basis. The federal police and the Brazilian Institute of Environment and Renewable Natural Resources (IBAMA), part of the Ministry of the Environment (MMA), began using satellite images provided by INPE to clamp down on illegal logging. There was, however, one major shortcoming in this surveillance system: the dense clouds that cover the Amazon during the rainy season were preventing the satellite's optical sensor from monitoring conditions on the ground. The breakthrough needed to resolve this issue came in the form of Japanese satellite technology.

In August 2006, JICA sent Manabu Kawaguchi, an expert in satellite image analysis, to Brazil for a period of six months to collaborate with IBAMA and the federal police to improve their environmental crime geographic information system. Kawaguchi concluded that the issue could be resolved by using data from DAICHI, the Advanced Land Observing Satellite (ALOS) operated by the Japan Aerospace Exploration Agency (JAXA), and he started to put his theory into practice. Launched by JAXA in 2006, ALOS uses a PULSAR microwave sensor instead of an optical sensor. This enables it to get a clear picture of the ground even in cloudy or rainy conditions, or at night. Whereas illegal loggers had previously been cutting down trees for half the year, hiding under cover during the rainy season, their activities are now exposed year-round, day and night. There may have been a degree of skepticism about Japanese technology in Brazil at the outset, but ALOS images have proved to be hugely effective in combating illegal logging. JAXA began providing ALOS data to IBAMA and the federal police in 2007, and in 2009 JICA launched the ALOS Satellite Image Utilization Project, together with IBAMA and the federal police, in order to improve ALOS imagery analysis capabilities. By using the results of this project, Brazil has greatly improved its satellite observation capabilities and its ability to crack down on illegal logging activities.

The utilization of ALOS images supported the Brazil-JICA project to identify deforestation and illegal logging in Brazil implemented between 2009 and 2012. The project contributed to the detection of more than 1000 deforestation and 150 illegal logging cases, respectively, from 2010 to 2011. The extent of forest decline in 2014 was 500,000 ha, which was about $80 \%$ less than the 2004 level. ${ }^{10}$ According to a study carried out by the Climate Policy Initiative (CPI), ${ }^{11}$ the control of illegal logging by satellite monitoring in the Amazon (DETER) ${ }^{12}$ impeded deforestation of more than $59,500 \mathrm{~km}^{2}$ during the period of 2007-2011. Deforestation in the period was $41,500 \mathrm{~km}^{2}$, which is $59 \%$ less than the estimated level without the control based on the satellite information (Valor Económico, May 5th, 2013). JAXA's ALOS system is the only such system in the world capable of providing satellite imagery around the clock. The use of ALOS to help prevent illegal logging marks a significant achievement in Japan-Brazil cooperation efforts.

Taking into account the experiences in Brazil, Japan International Cooperation Agency (JICA) and Japan Aerospace Exploration Agency (JAXA) launched a new Forest Governance Initiative in June 2016. For this initiative, JICA and JAXA have developed an early warning system for reducing deforestation of tropical forests: JICA-JAXA Forest Early Warning System in the Tropics by using JAXA's Advanced Land Observing Satellite (ALOS-2). The outstanding features of this system are: (1) ALOS-2 is able to capture images through the cloud; (2) The system monitors tropical forests every 1.5 months in 77 countries with a $50 \mathrm{~m}$ resolution; (3) The system allows free access from PCs and mobile devices from anywhere in the world. ${ }^{13}$ In order to improve forest resources management skills and promote environmental improvement for afforestation in Africa, JJFAST released monitoring data on deforestation and forest changes in the tropical regions in 43 countries during the 2016-2018 (TICAD VI period) (JICA 2019, 10). 


\subsection{Concluding Remarks}

Critical efforts to transform consumption and production patterns into those of, for example, circular economies and green economies, are necessary in order to achieve the improvement of human well-being and social equity, while significantly reducing environmental risks and ecological scarcities. The cases discussed in this chapter, especially Cases 7.1, 7.2, and 7.3, demonstrate that inclusive approaches, in which consumers and/or producers, as well as other stakeholders actively participate, is crucial. At the same time, innovative technologies and the accumulation of capabilities are both key. In this regard, several aspects related to learning and capacity development discussed in Chap. 4 could be observed in the above cases. For example, easy entry points can be identified in circular economies (such as 3R initiatives for both producers and consumers), in Kaizen activities, and green economies. Mutual learning and cocreation of innovative solutions are also relevant in these cases. The stakeholders who participated in efforts to transform consumption and/or production patterns incrementally developed appropriate solutions to address local and/or specific challenges. The costs and risks are relatively low when innovative activities are introduced incrementally.

Cases 7.3, 7.4, and 7.5 demonstrate that, in developing an inclusive green economy, environmental sustainability and adaptation to climate change can be strengthened through innovative and inclusive approaches. In these cases, innovative solutions, including technological and institutional innovations, facilitate opportunities for people to address the challenges of a green economy. In the case of the Tomé-Açu agroforestry model, innovative combinations of crops and trees, and the sequence in which they have been planted, are essential. In the Panama Canal watershed, innovative solutions were identified to promote the transition from slashand-burn farming to sustainable farming to produce staple foods and improve soil fertility. Throughout social forestry projects in Kenya, basic tree nursery and tree planting technologies in arid and semi-arid regions were developed, and core farmers were identified and their skills fostered. While these innovative solutions in terms of technology and institutions are important factors for achieving a green economy, they need to be practiced effectively by farmers, foresters and community members. These groups need to draw on their capacities, ownership and social capital if the goal is to achieve a transformational impact at the regional or country level or a full-fledged scale-up. Therefore, for a green economy, an inclusive and participatory approach is crucial.

In cases where natural capital is the essential endowment that enables the transformation, one of the key challenges for sustainable growth is to create institutions that are capable of monitoring and managing resources while supporting inclusive growth and poverty reduction through such growth, as demonstrated by Cases 7.6, 7.7, and 7.8. The activities of these institutions need to be supported by scientific research on the environmental, ecological and social impacts of the transformation, as well as developing effective monitoring systems.

\section{Notes}

1. The concept of 3Rs (Reduce, Reuse and Recycle) was incorporated in the Basic Law for Promotion of Development of a Circular Society enacted in 2000 in Japan. The country proposed the " $3 \mathrm{R}$ Initiative" at the G7 Summit in 2004 and an international ministerial meeting on 3R Initiative was held in 2005.

2. This paragraph draws on Kaiho Industry's web page: https://kaihosangyo.jp/english/.

3. This and the following paragraphs are based on information provided by JICA-Net. http://jica-net.jica.go.jp/lib2/07PRDM008, 2008.

4. This and the following three paragraphs draw on Hosono (2015) and Hosono and Hongo (2016).

5. A registry that uses a GIS to determine the borders of each farm, as well as the legal 
reserve and preservation districts in each part of owned land. Upon the request of a farm, expert contractors prepare digitized drawings of the land usage status inside each farm area. These electronic data are incorporated into Integrated Environmental Monitoring and Licensing databases operated by state government environmental agencies.

6. http://geocatalogo.mma.gov.br/.

7. This and the next paragraph draw from Sano (2019) and Hosono et al. (2019).

8. This paragraph is based on the project's web page: https://www.jst.go.jp/global/ english/kadai/h2905_chile.html.

9. The first four paragraphs of this section are based on Hosono and Hongo (2016).

10. Based on JJ-FAST webpage. https://www. eorc.jaxa.jp/jjfast/docs/JJ-FAST_EN.pdf.

11. CPI is an NGO financed by Open Society Foundations, supported by George Solos. In Brazil, the Foundations' partner is the Catholic University of Rio de Janeiro (PUC).

12. Deteccao de Desmatamentos em Tempo Real.

13. Based on JJ-FAST webpage. https://www. eorc.jaxa.jp/jjfast/docs/JJ-FAST_EN.pdf.

\section{References}

Development Bank of Japan (DBJ), Japan Economic Research Institute (JERI) (2003) Handbook for TQM and QCC. Inter-American Development Bank (IDB), Washington, DC

FAO, JICA, KFS (2011) Farmer field school implementation guide: farm forestry and livelihood development. FAO, JICA, and KFS

Hosono A (2013) Catalyzing an inclusive green economy through south-south and triangular cooperation: lessons learned from three relevant cases. In: JICA Research Institute (ed) Tackling global challenges through triangular cooperation: achieving sustainable development and eradicating poverty through the green economy. JICA-RI, Tokyo, pp 53-80

Hosono A (2015) Industrial transformation and quality of growth. In: Haddad L, Kato H, Meisel N (eds) Growth is dead, long live growth: the quality of economic growth and why it matters. JICA-RI, Tokyo, pp 267300
Hosono A, Hongo Y (2016) Cerrado agriculture and environment. In: Hosono A, da Rocha CMC, Hongo Y (eds) Development for sustainable agriculture: the Brazilian Cerrado. Palgrave and Macmillan, New York, pp 114-136

Hosono A, Hamaguchi N, Bojanic A (2019) Innovation with Spatial Impact: sustainable development of the Brazilian Cerrado. Springer, Singapore

Iizuka M (2016) Transformation of institutions: crisis and change in institutions for Chilean salmon industry. In: Hosono A, Iizuka M, Katz J (eds) Chile's salmon industry: policy challenges in managing public goods. Springer, Singapore, pp 137-174

Iizuka M, Zanlungo JP (2016) Environmental collapse and institutional restructuring: the sanitary crisis in the Chilean salmon industry. In: Hosono A, Iizuka M, Katz J (eds) Chile's salmon industry: policy challenges in managing public goods. Springer, Singapore, pp 109-138

Iizuka M, Hosono A, Katz J (2016) Introduction. In: Hosono A, Iizuka M, Katz J (eds) Chile's salmon industry: policy challenges in managing public goods. Springer, Singapore, pp 1-19

Japan International Cooperation Agency (JICA) (2003) Terminal evaluation on the social forestry extension model development project for semiarid areas. JICA, Tokyo

Japan International Cooperation Agency (JICA) (2004) Panama Canal Watershed Conservation Project (PROCCAPA) mid-term evaluation report (in Japanese). JICA, Tokyo

Japan International Cooperation Agency (JICA) (2005) Joint terminal evaluation report on the Panama Canal Watershed Conservation Project (PROCCAPA) in the Republic of Panama. JICA, Tokyo

Japan International Cooperation Agency (JICA) (2009) Summary of terminal evaluation on intensified social forestry project. JICA, Tokyo

Japan International Cooperation Agency (JICA) (2013) Internal ex-post evaluation for technical cooperation project: intensified social forestry project in semi-arid areas of Kenya. JICA, Tokyo

Japan International Cooperation Agency (JICA) (2019) JICA's initiatives in Africa: progress and achievements in activities for "investment for the future of Africa”. JICA, Tokyo

Katz J (2006) Economic, institutional and technological forces inducing the successful inception of salmon farming in Chile. In: Chandra V (ed) Technology, adaption and exports: how some countries got it right. World Bank, Washington, DC, pp 193-224

Lebdioni A (2019) Chile's export diversification since 1960: a free market miracle or mirage? Dev Change

Organization for Economic Co-operation and Development (OECD) (2008) Natural resources and pro-poor growth: the economics and politics. OECD, Paris

Organization for Economic Co-operation and Development (OECD) (2011) Towards green growth. OECD, Paris 
Piekielek J (2010) Cooperativism and agroforestry in the eastern Amazon: the case of Tomé-Açu. Lat Am Perspect 37:12

Sakai M, Ishida K-I (2002) Pacific salmon ranching in Southern Chile: evaluation of a project-type technical cooperation by JICA. In: Proceedings of international commemorative symposium 70th anniversary of the Japanese Society of Fisheries Science

Sano EE (2019) Land use expansion in the Brazilian Cerrado. In: Hosono A, Hamaguchi N, Bojanic A (eds) Innovation with spatial impact: sustainable development of the Brazilian Cerrado. Springer, Singapore, pp 137-162

Smith N, Dubois J, Current D, Lutz E, Clement C (1998) Agroforestry experiences in the Brazilian Amazon: constraints and opportunities. World Bank, Brasilia

United Nations (2015) Transforming our world: the 2030 agenda for sustainable development. https:// sustainabledevelopment.un.org/content/documents

Open Access This chapter is licensed under the terms of the Creative Commons Attribution-NonCommercialNoDerivatives 4.0 International License (http:// creativecommons.org/licenses/by-nc-nd/4.0/), which permits any noncommercial use, sharing, distribution and reproduction in any medium or format, as long as you give appropriate credit to the original author(s) and the source, provide a link to the Creative Commons license and indicate if you modified the licensed material. You do not have permission under this license to share adapted material derived from this chapter or parts of it.
United Nations Conference on Sustainable Development (2012) The future we want. https://sustainable development.un.org/content/documents

United Nations Conference on Trade and Development (UNCTAD) (2017) Circular economy: the new normal? Policy brief no. 61. UNCTAD

United Nations Economic and Social Commission for Asia and the Pacific (UN-ESCAP) (2013) Shifting from quantity to quality: growth with equality, efficiency, sustainability and dynamism. UNESCAP, Bangkok

United Nations Environment Program (UNEP) (2011) Towards a green economy: pathways to sustainable development and poverty reduction. UNDP, Nairobi

World Bank (2020) World development report 2020: trading for development in the age of global value chains. World Bank, Washington, DC

Yamada M (2003) Amazon tropical rain forest and agroforestry. Geography (in Japanese)

The images or other third party material in this chapter are included in the chapter's Creative Commons license, unless indicated otherwise in a credit line to the material. If material is not included in the chapter's Creative Commons license and your intended use is not permitted by statutory regulation or exceeds the permitted use, you will need to obtain permission directly from the copyright holder.

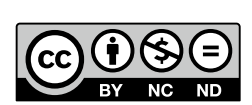

